\title{
Avoiding imports in Japan
}

\section{Tokyo}

Pl.ANS are afoot to drastically re-structure the blood-product industry in Japan to reduce dependence on imported blood products which were the main source of AIDS infection. But the re-structuring could result in increased prices for blood coagulants for haemophiliacs, the main victims of AIDS in Japan.

A report released this month by an advisory body to the Ministry of Health and Welfare, the New Blood Business Promotion Study Council, recommends that all production of blood coagulants should be transferred from the private sector to the Japan Red Cross by 1991 and that coagulants should be made only from domestic blood. Until now, all coagulants have been made by private companies IVORY IMPORTS using mostly cheap US blood plasma. The report also recommends that more domestic blood should be used in the production of other blood products, such as albumin and globulin, and a new public organization should oversee the blood business in Japan.

Japan has come under international criticism for its excessive imports of blood products. In 1975, the World Health Organization (WHO) recommended that blood products should be made from domestic blood supplies. But by the mid1980 s, Japan's imports of blood plasma had grown to occupy about a third of the world market, and domestic blood supplied only a few per cent of demand. Coincident with this surge in the use of imported blood, AIDS was introduced to

\section{Japanese importers slide under the wire}

\section{Tokyo}

IT seems to be impossible to stop Japan's ivory importers. In June, the Ministry of International Trade and Industry (MITI) announced a partial ban on ivory imports in the face of international criticism and concern about dwindling populations of elephants in Africa (Nature 340,$85 ; 1989$ ). But no sooner was the partial ban announced than Japanese importers began stockpiling imported ivory on a large scale.

The stockpiling came to light after MITI announced on 13 September a "temporary" total ban on imports as part of a new import quota system intended to prevent exactly what has happened.

The earlier ban, affecting all imports of worked ivory, also banned indirect imports of raw ivory from suppliers in places such as Hong Kong and Singapore. Announced by MITI on 16 June, it took effect only three days later, but in the interval Japanese importers had placed orders in Hong Kong for about 20 tonnes of raw ivory, or about 20 per cent of Japan's annual use in recent years, according to Toru Takimoto of MITI's International Trade Administration Bureau.

Even after the partial ban took effect, direct imports from Africa continued, reaching by this month about 100 tonnes, or about as much as for the whole of last year. This stockpiling seems not to have been affected by the undertaking on 15 June to show "self-restraint by the several Japanese organizations involved in the import of ivory" (Japan General Merchandise Importers' Association, Japan Ivory Fine Arts and Crafts Cooperation Federation, Tokyo Ivory Fine Arts and Crafts Association and Osaka Ivory Fine Arts and Crafts Association).

The stockpiling has not yet shown up in import statistics because the ivory has been deliberately held in bonded warehouses so as not to appear in customs-cleared trade statistics. But international embarrassment will be unavoidable when the trade figures for August appear any day now, according to a wellinformed source.

Japan imports almost half of the world's ivory. The industry is worth about $\$ 20,000$ million ( $\$ 140$ million) a year and supports about 30,000 employees. Over half of the imports go into the manufacture of pencil-sized personal seals that can cost as much as $¥ 80,000$ (\$550) for a set of three. When the various ivory trade organizations pledged to show "selfrestraint" in June, they also expressed their hope to continue their business no matter how "frugal" it might be.

The United States, European nations and several other countries have imposed total bans on ivory imports. And there are strong international pressures to impose a total import ban under the Convention on International Trade in Endangered Species (CITES) to which Japan is a party. A CITES meeting to vote on the issue will be held next month in Switzerland.

MITI said in July that while, "in principle", Japan favours a total ban, there are some countries (notably South Africa, Zimababwe and Botswana) that wish to continue trade on a sustainable basis and "it is not proper to disregard their intention and deprive them of economic resources unilaterally". Takimoto says MITI will decide on the length of its present temporary total import ban after next month's CITES meeting. But critics say the temporary ban is just a "cosmetic" measure for the meeting in Switzerland.

David Swinbanks
Japan in non-heat-treated blood coagulants made from US plasma and more than 90 per cent of AIDS carriers in Japan are haemophiliacs who were treated with such products.

The Ministry of Health and Welfare has tried to reduce consumption of blood products by discouraging unnecessary prescription by doctors. Consumption of blood plasma dropped from a peak of 3.8 million litres in 1985 to 2.7 million litres in 1987 but has since risen to $2 \cdot 8$ million litres in 1988 . On a per capita basis, this is still more than twice the consumption of the United Kingdom and France, for example (see Nature 322, 193; 1988).

The driving force behind blood consumption in Japan is huge discounting by pharmaceutical companies. The health and welfare ministry sets 'official' prices for drugs in April each year. But by using cheap imported blood plasma and blood products, companies have been selling blood products at far below the official price. Hospitals, which charge patients and the national health insurance system the official price, have been able to reap enormous profits by prescribing more and more blood products. The council report calls for production of cheaper domestic products to compete with imports. But experts express scepticism about the ability of the Red Cross to take over the blood coagulant business and produce cheap products.

A recent report in the Japanese newsletter Nikkei Biotechnology points out that the cost of blood plasma produced by the Japanese Red Cross ( $¥ 45$ or out $\$ 0 \cdot 3$ per millilitre) is five times that of imported plasma and about seven times the price of plasma in the United States. Part of the reason for the high cost is that about 80 per cent of the blood is collected by mobile blood donation vans which are not cost effective. Unless the efficiency of blood collection is improved, the cost of domestically produced blood products is unlikely to fall.

The Nikkei Biotechnology report also doubts whether the Red Cross will be able to produce all blood coagulants by 1991 . Although Japan has one of the highest blood donation rates in the world, most of the blood is used for transfusions, leaving little for production of blood-plasma products. The council report calls for blood donations to be increased from about 1.9 million litres in 1988 to 2.3 million litres in 1991 to supply the bloodplasma necessary for domestic bloodcoagulant production.

But this target is insufficient if conventional methods of blood-coagulant production are used. A new monoclonalantibody technique developed by Baxter pharmaceutical company in the United States gives a higher yield of blood coagulant and could perhaps meet Japan's domestic needs. The council report calls 